Fifth International Conference on Sustainable Construction Materials and

Technologies. http://www.claisse.info/Proceedings.htm

This manuscript is for Professor Cheesman's session

\title{
THE INFLUENCE OF CALCIUM SOURCE ON THE PREPARATION OF GEOPOLYMER USING CIRCULATING FLUIDIZED BED FLY ASH
}

Xiu-chen Qiao

School of Resource and Environmental Engineering, East China University of Science and Technology, 130 Meilong Road, Shanghai, China, 200237.

Tel: 86-21-64250182, Email: xiuchenqiao@ecust.edu.cn

\begin{abstract}
Circulating fluidized bed (CFB) fly ash contains a high content of calcium and sulfur, which makes it difficult to be used as traditional construction and building materials. However, the chemical compositions and mineral compositions of CFB fly ash showed potential application in the synthesis of geopolymer. A mixture of metakaolin and $\mathrm{CaCO}_{3}, \mathrm{CaSO}_{4}$ and $\mathrm{Ca}(\mathrm{OH})_{2}$ was used to investigate the influence of calcium source on the preparation of geopolymer in the $\mathrm{SiO}_{2}-\mathrm{Al}_{2} \mathrm{O}_{3}-\mathrm{CaO}-\mathrm{Na}_{2} \mathrm{O}-\mathrm{H}_{2} \mathrm{O}$ system. The results showed that the presence of $\mathrm{CaCO}_{3}$ played a catalytic role and accelerated the setting process. The $\mathrm{CaCO}_{3}$-bearing sample showed the highest strength development at early curing age when the $\mathrm{CaO} / \mathrm{Al}_{2} \mathrm{O}_{3}$ was 0.5 , however, showed the highest after long-term curing when the $\mathrm{CaO} / \mathrm{Al}_{2} \mathrm{O}_{3}$ was 0.1 . New phases faujasite and zeolite formed in 90 day cured $\mathrm{CaCO}_{3}$-bearing samples. When the $\mathrm{CaO} / \mathrm{Al}_{2} \mathrm{O}_{3}$ was higher than 0.3 the $\mathrm{CaSO}_{4}$-bearing sample quick set due to the formation of AFt. When the $\mathrm{CaO} / \mathrm{Al}_{2} \mathrm{O}_{3}$ was 0.5 the 28 day cured $\mathrm{CaSO}_{4}$-bearing sample showed a strength reduction due to continuous formation of $\mathrm{AFt}$. New phases including thenardite and faujasite formed in $\mathrm{CaSO}_{4}$-bearing sample. The pozzolanic reaction and the geopolymerization reaction were the main reactions in the $\mathrm{Ca}(\mathrm{OH})_{2}$-bearing samples.
\end{abstract}

Keywords: Geopolymer, pozzolanic reaction, metakaolin, Circulating fluidized bed, fly ash 


\section{INTRODUCTION}

Circulating fluidized bed (CFB) boilers showed advantages in the combustion of coal wastes and won their high acceptability for power plants in past twenty years in China. The quantities of combustion bottom and fly ash of CFB boiler were 2-3 times higher than those of pulverized coal fly ash. CFB ash contains a high content of calcium and sulfur due to desulphurization, which makes it difficult to be used as traditional construction and building materials. However, the chemical compositions and mineral compositions of CFB ash showed potential application in the synthesis of geopolymer.

Geopolymers are inorganic, typically ceramic, materials that form long-range, covalently bonded, three dimensional amorphous networks, similar to zeolites (Huang, Y. and Han, M., 2011). Metal cations such as $\mathrm{Na}^{+}, \mathrm{K}^{+}$and $\mathrm{Ca}^{2+}$ in the networks balanced the charge associated with tetrahedral Al (Feng, D. et al., 2012). There were N-PS 、 N-PSS and N-PSDS geopolymers depending on the $\mathrm{SiO}_{2} / \mathrm{Al}_{2} \mathrm{O}_{3}$ ratio (Pimraksaa, K. et al., 2011). The investigations on the preparation of geopolymers have lasted for more than half a century. Generally, the mechanism of geopolymerization can be divided into three main stages (Part W. K. et al., 2015): (1) Dissolution of oxide minerals from the source materials (usually silica and alumina) under highly alkaline condition; (2) transportation/orientation of dissolved oxide minerals, followed by coagulation /gelation; (3) polycondensation to form 3D network of silico-aluminates structures. The availability of dissolved $\mathrm{Al}$ and $\mathrm{Si}$ at a given moment highly influenced the kinetics of the alkaline activation of alumino-silicate materials (Fernández-Jiménez A. et al., 2006). The $\mathrm{Na} / \mathrm{Si}$ ratio was positively related with the formation of aluminosilicate gel N-A-S-H (Criado M. et al., 2007) and the Na/Al ratio showed important effects on the formation of 3D network (Zhang Z. et al, 2012). The presence of $\mathrm{Ca}(\mathrm{OH})_{2}$ showed influences on the formation of $\mathrm{C}-\mathrm{S}-\mathrm{H}$, however, not on the formation of N-A-S-H (Alonso S. and Palomo A., 2001). However, many questions persist about the reactivity of alumino-silicate materials in strong alkaline environments and soluble silicates.

In this research a mixture of metakaolin and $\mathrm{CaCO}_{3}, \mathrm{CaSO}_{4}$ and $\mathrm{Ca}(\mathrm{OH})_{2}$ instead of CFB fly ash was used to investigate the influence of $\mathrm{Na}_{2} \mathrm{O} / \mathrm{Al}_{2} \mathrm{O}_{3}, \mathrm{SiO}_{2} / \mathrm{Al}_{2} \mathrm{O}_{3}$ and pozzolanic reaction on the setting time and compressive strength of geopolymer.

\section{EXPERIMENTAL}

\section{Geopolymer Paste Formulation}

The metakaolin material used in this research was prepared by heating a commercial kaolinite (D95 <0.08mm) at $860{ }^{\circ} \mathrm{C}$ for $3 \mathrm{~min}$. Chemical compositions of the metakaolin determined by X-ray fluorescence (XRF) spectroscopy (Thermo Fisher Scientific, ARL ADVANT 3600, America) were shown in Table 1. A sodium silicate solution with $27.3 \% \mathrm{SiO}_{2}, 8.36 \% \mathrm{Na}_{2} \mathrm{O}$ and $64.34 \% \mathrm{H}_{2} \mathrm{O}$ and $\mathrm{AR}$-grade $\mathrm{NaOH}, \mathrm{CaCO}_{3}$ $\mathrm{Ca}(\mathrm{OH})_{2}$ and $\mathrm{Ca}(\mathrm{SO})_{4}$ were used as additives. The mix formulation of geopolymer 
paste was shown in Table 2. The sample with the addition of $\mathrm{CaCO}_{3}$ was denoted as $\mathrm{CC}, \mathrm{CS}$ for $\mathrm{CaSO}_{4}, \mathrm{CH}$ for $\mathrm{Ca}(\mathrm{OH})_{2}$.

Table.1 Chemical compositions of metakaolin (wt $\%$ )

\begin{tabular}{llllll}
\hline $\mathrm{SiO}_{2}$ & $\mathrm{Al}_{2} \mathrm{O}_{3}$ & $\mathrm{CaO}$ & $\mathrm{Fe}_{2} \mathrm{O}_{3}$ & $\mathrm{SO}_{3}$ & LOI \\
\hline 54.67 & 41.61 & 0.11 & 0.15 & 0.47 & 1.89 \\
\hline
\end{tabular}

Table.2 Mix proportion of experimental material (wt $\%)$

\begin{tabular}{|c|c|c|c|c|c|c|c|c|}
\hline Sample & Designed composition & MK & $\begin{array}{c}\mathrm{CaC} \\
\mathrm{O}_{3}\end{array}$ & $\begin{array}{c}\mathrm{Ca}(\mathrm{OH}) \\
2\end{array}$ & $\mathrm{CaSO}_{4}$ & $\mathrm{NaOH}$ & $\begin{array}{c}\mathrm{Na}_{2} \mathrm{Si} \\
\mathrm{O}_{3}\end{array}$ & $\mathrm{H}_{2} \mathrm{O}$ \\
\hline CC- 0.1 & $\begin{array}{l}2.4 \mathrm{SiO}_{2} \cdot \mathrm{Al}_{2} \mathrm{O}_{3} \cdot 0.7 \mathrm{Na}_{2} \mathrm{O} \cdot 0 . \\
1 \mathrm{CaO}\end{array}$ & 57.79 & 2.37 & - & - & 12.31 & 3.10 & 24.25 \\
\hline CC- 0.2 & $\begin{array}{l}2.4 \mathrm{SiO}_{2} \cdot \mathrm{Al}_{2} \mathrm{O}_{3} \cdot 0.7 \mathrm{Na}_{2} \mathrm{O} \cdot 0 \\
2 \mathrm{CaO}\end{array}$ & 56.63 & 4.62 & - & - & 12.03 & 3.03 & 23.69 \\
\hline CC- 0.3 & $\begin{array}{l}2.4 \mathrm{SiO}_{2} \cdot \mathrm{Al}_{2} \mathrm{O}_{3} \cdot 0.7 \mathrm{Na}_{2} \mathrm{O} \cdot 0 \\
3 \mathrm{CaO}\end{array}$ & 55.35 & 6.78 & - & - & 11.75 & 2.96 & 23.16 \\
\hline CC- 0.5 & $\begin{array}{l}2.4 \mathrm{SiO}_{2} \cdot \mathrm{Al}_{2} \mathrm{O}_{3} \cdot 0.7 \mathrm{Na}_{2} \mathrm{O} \cdot 0 . \\
5 \mathrm{CaO}\end{array}$ & 52.96 & 10.81 & - & - & 11.25 & 2.83 & 22.16 \\
\hline CS-0.1 & $\begin{array}{l}2.4 \mathrm{SiO}_{2} \cdot \mathrm{Al}_{2} \mathrm{O}_{3} \cdot 0.7 \mathrm{Na}_{2} \mathrm{O} \cdot 0 \\
1 \mathrm{CaO}\end{array}$ & 57.48 & - & - & 3.19 & 12.21 & 3.08 & 24.05 \\
\hline CS-0.2 & $\begin{array}{l}2.4 \mathrm{SiO}_{2} \cdot \mathrm{Al}_{2} \mathrm{O}_{3} \cdot 0.7 \mathrm{Na}_{2} \mathrm{O} \cdot 0 \\
2 \mathrm{CaO}\end{array}$ & 55.70 & - & - & 6.19 & 11.83 & 2.98 & 23.30 \\
\hline CS-0.3 & $\begin{array}{l}2.4 \mathrm{SiO}_{2} \cdot \mathrm{Al}_{2} \mathrm{O}_{3} \cdot 0.7 \mathrm{Na}_{2} \mathrm{O} \cdot 0 . \\
3 \mathrm{CaO}\end{array}$ & 54.03 & - & - & 9.01 & 11.47 & 2.89 & 22.60 \\
\hline CS- 0.5 & $\begin{array}{l}2.4 \mathrm{SiO}_{2} \cdot \mathrm{Al}_{2} \mathrm{O}_{3} \cdot 0.7 \mathrm{Na}_{2} \mathrm{O} \cdot 0 . \\
5 \mathrm{CaO}\end{array}$ & 50.97 & - & - & 14.16 & 10.82 & 2.73 & 21.32 \\
\hline CH-0.1 & $\begin{array}{l}2.5 \mathrm{SiO}_{2} \cdot \mathrm{Al}_{2} \mathrm{O}_{3} \cdot 0.3 \mathrm{Na}_{2} \mathrm{O} \cdot 0 . \\
1 \mathrm{CaO}\end{array}$ & 62.20 & - & 1.98 & - & 4.48 & 5.32 & 26.02 \\
\hline $\mathrm{CH}-0.2$ & $\begin{array}{l}2.5 \mathrm{SiO}_{2} \cdot \mathrm{Al}_{2} \mathrm{O}_{3} \cdot 0.3 \mathrm{Na}_{2} \mathrm{O} \cdot 0 \\
2 \mathrm{CaO}\end{array}$ & 60.99 & - & 3.88 & - & 4.40 & 5.21 & 25.52 \\
\hline $\mathrm{CH}-0.3$ & $\begin{array}{l}2.5 \mathrm{SiO}_{2} \cdot \mathrm{Al}_{2} \mathrm{O}_{3} \cdot 0.3 \mathrm{Na}_{2} \mathrm{O} \cdot 0 \\
3 \mathrm{CaO}\end{array}$ & 59.83 & - & 5.71 & - & 4.31 & 5.12 & 25.03 \\
\hline $\mathrm{CH}-0.5$ & $\begin{array}{l}2.5 \mathrm{SiO}_{2} \cdot \mathrm{Al}_{2} \mathrm{O}_{3} \cdot 0.3 \mathrm{Na}_{2} \mathrm{O} \cdot 0 \\
5 \mathrm{CaO}\end{array}$ & 57.63 & - & 9.17 & - & 4.15 & 4.93 & 24.11 \\
\hline
\end{tabular}

\section{Characterization of Geopolymers}

The setting time for all mixes with $\mathrm{w} /$ silica of 2.10 was determined using a Vicat needle $(1.13 \pm 0.05 \mathrm{~mm})$ following the procedure outlined in GB/T1346. The initial setting time was the elapsed time after sample mixing when the distance between the needle and the base-plate supporting the sample is $4 \pm 1 \mathrm{~mm}$. The final setting was the elapsed time when the needle only penetrates $0.5 \mathrm{~mm}$ into the specimen. Three specimens per mix were subject to compressive strength testing after curing for 1, 3, 7, 28 and 90 days. The strength results reported were the average of three specimens and varied by 
not more than $10 \%$.

The hydration reactions were stopped after required curing days by immersing samples in ethanol for 7 days, with the ethanol replaced with fresh solution after the first 4 days. Samples were then dried at $45^{\circ} \mathrm{C}$ for $48 \mathrm{~h}$ and ground to pass through a $76 \mu \mathrm{m}$ sieve. The ground samples were then used to determine the crystalline phases presented by $\mathrm{X}$-ray diffraction (XRD, Rigaku D/MAX $2550 \mathrm{VB}$ with a $\mathrm{Cu}$ target) and the structure variation by Raman spectrum measurement (Thermo Fisher, DXR, Laser wavelength $445 \mathrm{~nm})$.

\section{RESULTS AND DISCUSSION}

\section{Influence of $\mathrm{CaCO}_{3}$ on the Geopolymerization}

The results in Figure 1 showed that with the increase of $\mathrm{CaO} / \mathrm{Al}_{2} \mathrm{O}_{3}$ molar ratio from 0.1 to 0.5 the initial setting time of sample $\mathrm{CC}$ varied from $271 \mathrm{~min}$ to $15 \mathrm{~min}$, the finial setting time accelerated from $575 \mathrm{~min}$ to $38 \mathrm{~min}$. The reactions occurred in the $\mathrm{SiO}_{2}-\mathrm{Al}_{2} \mathrm{O}_{3}-\mathrm{CaO}-\mathrm{Na}_{2} \mathrm{O}-\mathrm{H}_{2} \mathrm{O}$ system of this research are shown in Equations 1-8 (Silva P. D. et al., 2014 and Suryavanshi A. K. et al. 1996). The geopolymerization began with the structure breakdown of metakaolin under the attack of alkaline activators, i.e. Equation 1. This reaction was dependent on the concentration of $\mathrm{NaOH}$ (Alonso S. and Palomo A., 2001). However, the presence of $\mathrm{CaCO}_{3}$ accelerated Equations 1-8 (Rakhimova N. R. et al., 2016 and Gao X. et al., 2015). The presence of $\mathrm{CaCO}_{3}$ also acted as fine aggregates to lower down the porosity of samples, which increased the compressive strength of early age cured samples with the increase of $\mathrm{CaO} / \mathrm{Al}_{2} \mathrm{O}_{3}$ (Figure 2). However, the development of compressive strength varied with curing ages and $\mathrm{CaO} / \mathrm{Al}_{2} \mathrm{O}_{3}$. The compressive strength of sample $\mathrm{CC}-0.5$ was $9.1 \mathrm{MPa}$ after 1 -day curing, increased to 14.3 and 17.2MPa after 3 and 7-day curing. After curing for 28 and 90 days the compressive strengths of sample CC-0.1 were 26.4 and $29.0 \mathrm{MPa}$, respectively, which was the highest (Figure 2).

$$
\begin{gathered}
\mathrm{Si}_{2} \mathrm{O}_{5} \cdot \mathrm{Al}_{2} \mathrm{O}_{2} \stackrel{\mathrm{OH}^{-}}{\longrightarrow} \mathrm{SiO}_{2}(\mathrm{OH})_{2}^{2-} \text { orSiO }(\mathrm{OH})_{3}^{-}+\mathrm{Al}(\mathrm{OH})_{4}^{-} \\
2 \mathrm{Al}(\mathrm{OH})_{4}^{-}+3 \mathrm{Ca}^{2+}+4 \mathrm{OH}^{-} \leftrightarrow 3 \mathrm{CaO} \cdot \mathrm{Al}_{2} \mathrm{O}_{3} \cdot 6 \mathrm{H}_{2} \mathrm{O} \\
\mathrm{SiO}_{2}(\mathrm{OH})_{2}^{2-} \text { or SiO }(\mathrm{OH})_{3}^{-}+x \mathrm{Ca}^{2+}+(y-x) \mathrm{H}_{2} \mathrm{O} \\
\rightarrow x \mathrm{CaO} \cdot \mathrm{SiO} \mathrm{O}_{2} \cdot y \mathrm{H}_{2} \mathrm{O} \\
x \mathrm{SiO}_{2}(\mathrm{OH})_{2}^{2-} \text { or SiO }(\mathrm{OH})_{3}^{-}+\mathrm{Al}(\mathrm{OH})_{4}^{-}+\mathrm{Ca}^{2+} \rightarrow \mathrm{CASH} \mathrm{gel} \\
x \mathrm{SiO}_{2}(\mathrm{OH})_{2}^{2-} \text { orSiO }(\mathrm{OH})_{3}^{-}+\mathrm{Al}(\mathrm{OH})_{4}^{-}+\mathrm{Na}^{+} \rightarrow \mathrm{NASHgel} \\
\mathrm{Al}(\mathrm{OH})_{4}^{-}+2 \mathrm{OH}^{-} \rightarrow \mathrm{Al}(\mathrm{OH})_{6}^{3-} \\
\mathrm{Al}(\mathrm{OH})_{6}^{3-}+3 \mathrm{Ca}^{2+}+12 \mathrm{H}_{2} \mathrm{O} \rightarrow\left[\mathrm{Ca}_{3} \mathrm{Al}(\mathrm{OH})_{6} \cdot 12 \mathrm{H}_{2} \mathrm{O}^{3+}\right. \\
2 \mathrm{Al}(\mathrm{OH})_{4}^{-}+3 \mathrm{Ca}^{2+}+3 \mathrm{SiO}_{3}^{2-} \\
\rightarrow 3 \mathrm{CaO} \cdot \mathrm{Al}_{2} \mathrm{O}_{3} \cdot 3 \mathrm{SiO}_{2}+2 \mathrm{OH}^{-}+3 \mathrm{H}_{2} \mathrm{O}
\end{gathered}
$$




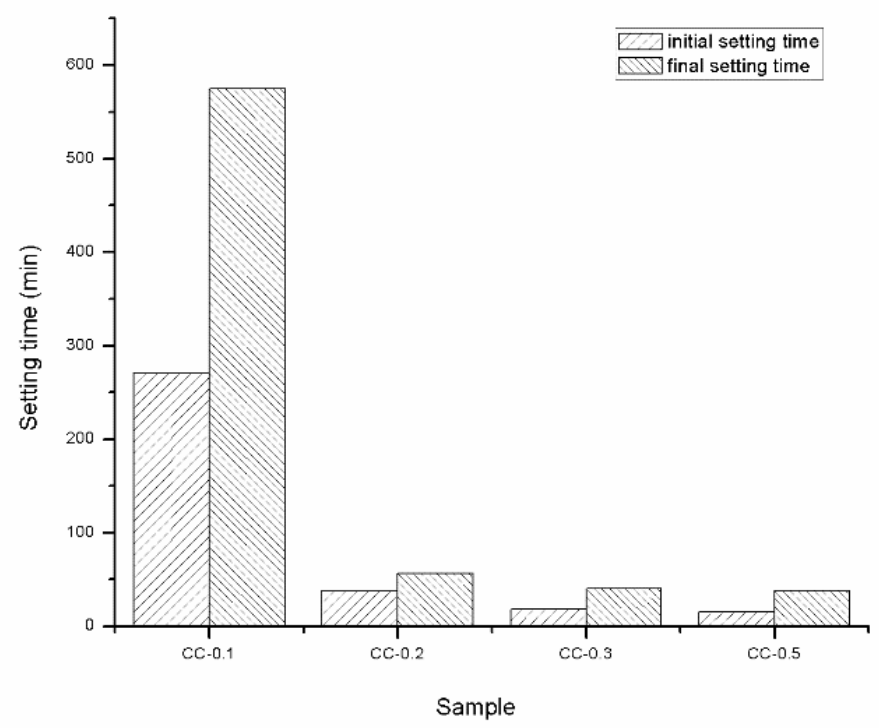

Figure 1. Setting time of each $\mathrm{CaCO}_{3}$-bearing sample.

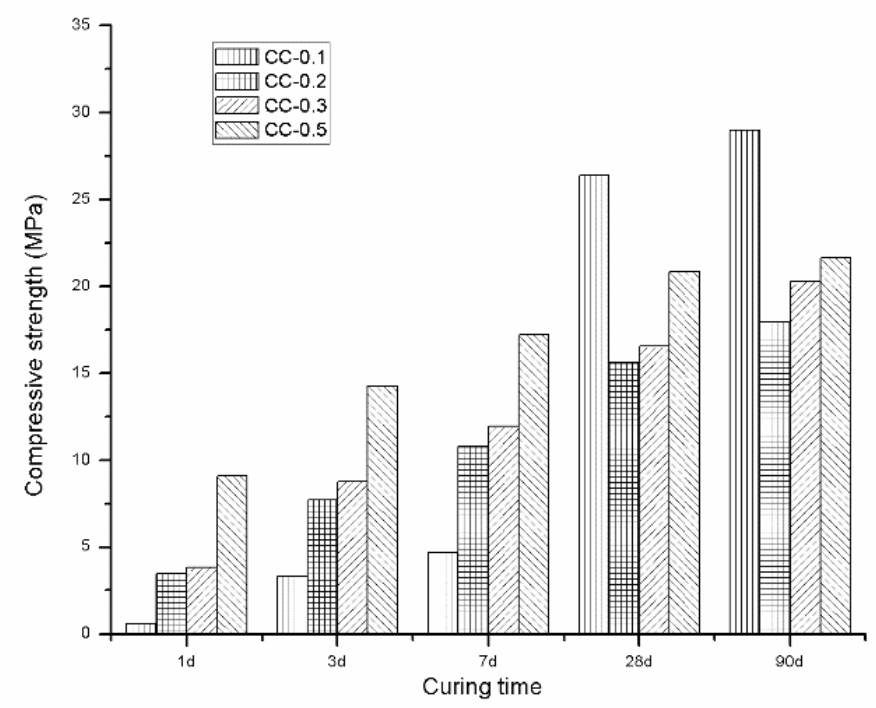

Figure 2. Compressive strengths of $\mathrm{CaCO}_{3}$-bearing samples.

The results in Figure 3 showed that calcite $\left(\mathrm{CaCO}_{3}\right)$ in sample decreased with curing ages. Quartz was detected in all samples, which suggested the presence of metakaolin in all curing age samples. A new phase faujasite formed after 90-day curing, which was the evidence of geopolymerization. It formed more in sample CC- 0.1 than in 
sample CC-0.5. Zeolite formed in 90-day cured sample CC-0.5, however, was not detected in sample CC-0.1. The influence of $\mathrm{CaCO}_{3}$ on geopolymerization varied with $\mathrm{CaO} / \mathrm{Al}_{2} \mathrm{O}_{3}$ and curing ages.

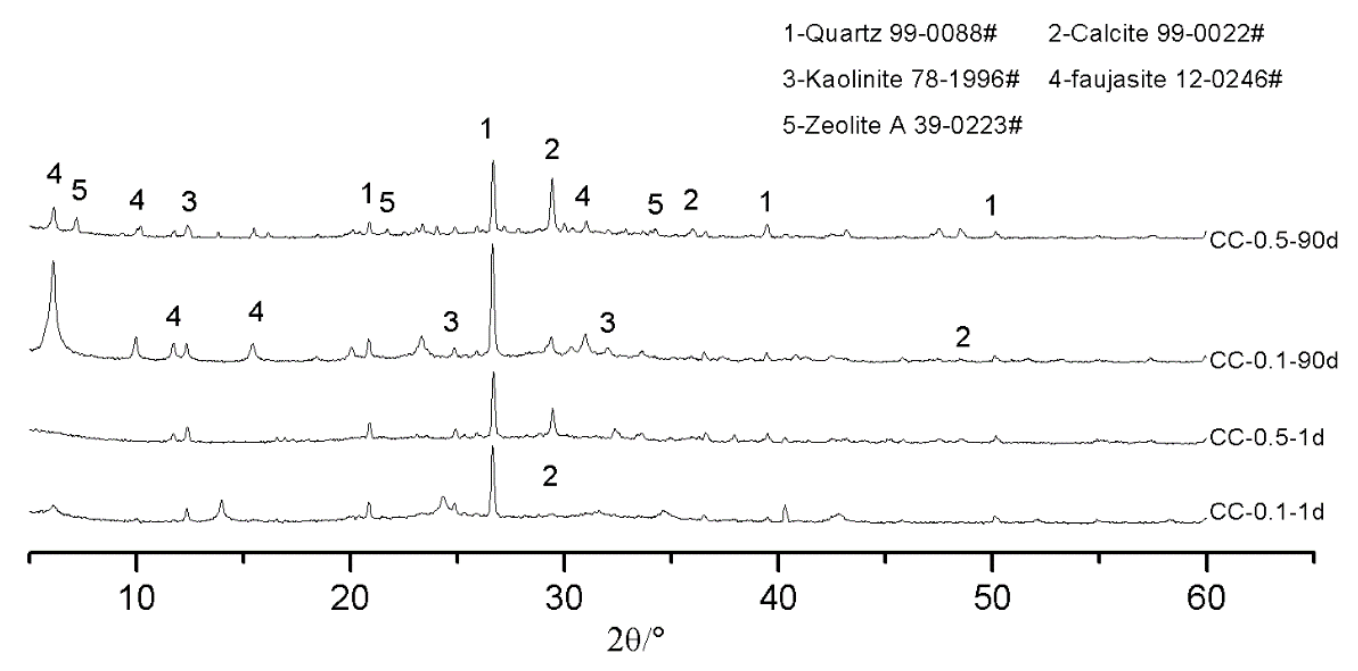

Figure 3. X-ray diffraction patterns of $\mathrm{CaCO}_{3}$-bearing samples (normalized to the $100 \%$ intensity peak of quartz of sample CC-0.1-1d )

\section{Influence of $\mathrm{CaSO}_{4}$ on the Geopolymerization}

The results in Figure 5 showed that setting time decreased with the increase of $\mathrm{CaSO}_{4}$. When the $\mathrm{CaO} / \mathrm{Al}_{2} \mathrm{O}_{3}$ was higher than 0.3 , i.e. $\mathrm{SO}_{3}$ in solid was $6.85 \%$, the sample quick set. With the increase of the $\mathrm{CaO} / \mathrm{Al}_{2} \mathrm{O}_{3}$ from 0.1 to 0.5 the initial setting time of sample CS accelerated from $1260 \mathrm{~min}$ to $20 \mathrm{~min}$, the finial setting time was from $1380 \mathrm{~min}$ to $80 \mathrm{~min}$. Comparing to the lower solubility of $\mathrm{CaCO}_{3}\left(\mathrm{Ksp}=3.3 \times 10^{-9}\right)$ higher solubility of $\mathrm{CaSO}_{4}\left(\mathrm{Ksp}=3.14 \times 10^{-5}\right)$ accelerated Equations $2-4$ and 7-8 at the same $\mathrm{CaO} / \mathrm{Al}_{2} \mathrm{O}_{3}$. The presence of $\mathrm{CaSO}_{4}$ resulted in the formation of AFt (Equation 9). An appropriate amount of AFt showed the effect of retarding the initial setting time, however, too much formation of AFt accelerated the setting time due to fast reaction rate of Equation 9 and needle like morphology of AFt. The formed $\mathrm{Na}_{2} \mathrm{SO}_{4}$ due to Equation 10 also accelerated the setting time (Qiao X.C. et al., 2009).

$$
\begin{aligned}
2\left[\mathrm{Ca}_{3} \mathrm{Al}(\mathrm{OH})_{6} \cdot 12 \mathrm{H}_{2} \mathrm{O}\right]^{3+}+3 \mathrm{SO}_{4}^{2-}+8 \mathrm{H}_{2} \mathrm{O} \\
\rightarrow 3 \mathrm{CaO} \cdot \mathrm{Al}_{2} \mathrm{O}_{3} \cdot 3 \mathrm{CaSO}_{4} \cdot 32 \mathrm{H}_{2} \mathrm{O} \\
\mathrm{CaSO}_{4}+\mathrm{NaOH} \rightarrow \mathrm{Na}_{2} \mathrm{SO}_{4}+\mathrm{Ca}(\mathrm{OH})_{2}
\end{aligned}
$$




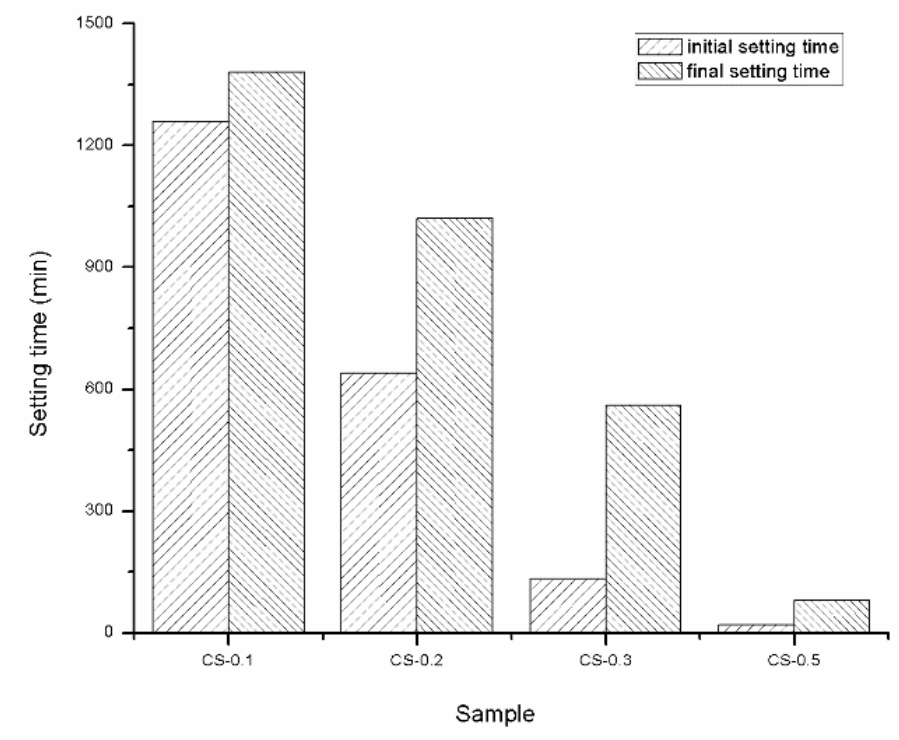

Figure 4. Setting time of each $\mathrm{CaSO}_{4}$-bearing sample.

The compressive strength of early age cured samples increased with the increase of $\mathrm{CaSO}_{4}$ (Figure 5). The sample CS-0.5 showed a strength of $27.00 \mathrm{MPa}$ after 1-day curing and reached $35.9 \mathrm{MPa}$ after 7-day curing. After curing for 28 days the strength of sample CS-0.5 lowered down to $29.7 \mathrm{MPa}$, although the other three samples' increased. After curing for 90 days the strength of samples CS-0.1, CS- 0.2 and CS-0.3 largely increased and the sample CS- 0.3 showed the highest strength of $44.3 \mathrm{MPa}$. The 90 day cured sample CS- 0.5 was only $34.6 \mathrm{MPa}$. The strength reduction of sample CS0.5 after 28 day curing was due to the formation of large amount of AFt vibrated at $995 \mathrm{~cm}^{-1}$ (Figure 6), which was consistent with the setting time. The formation of AFt at long-term curing ages would lead to crack due to volume expansion. 


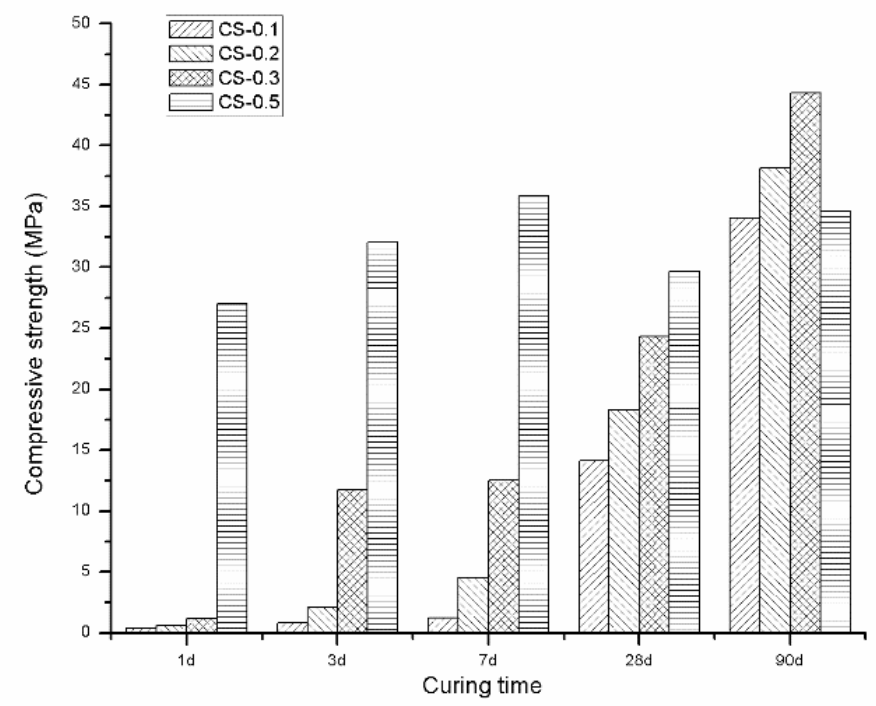

Figure 5. Compressive strengths of $\mathrm{CaSO}_{4}$-bearing samples.

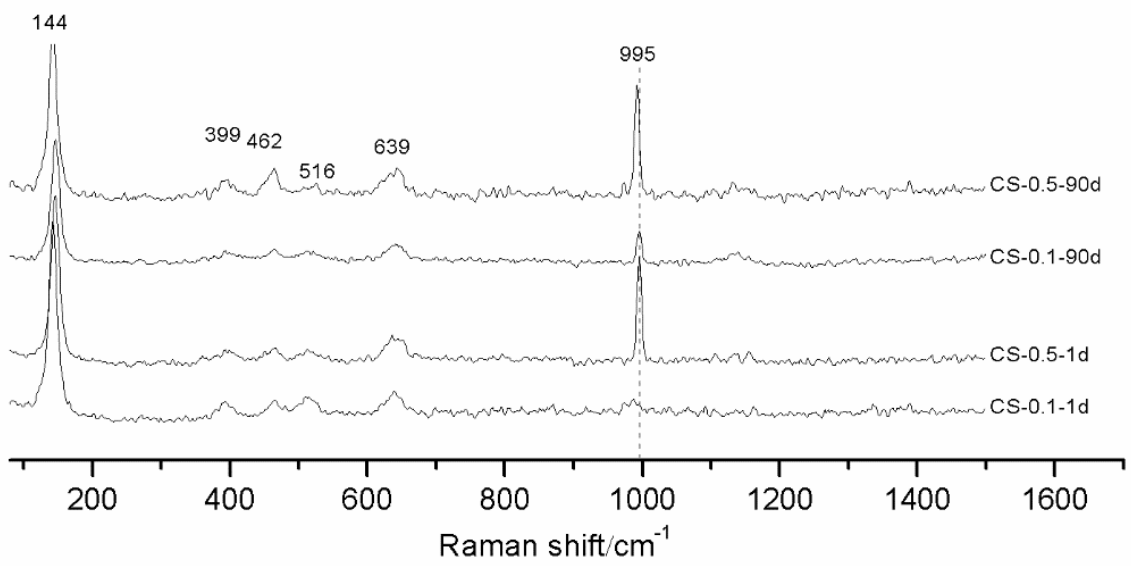

Figure 6. Raman spectra of $\mathrm{CaSO}_{4}$-bearing samples.

Although the Raman spectra showed the formation of AFt the XRD results in Figure 7 did not find obvious AFt peaks. Some new phases including thenardite and faujasite accounted for the geopolymerization. The characterization peaks of $\mathrm{CaSO}_{4}, \mathrm{Na}_{2} \mathrm{SO}_{4}$ and $\mathrm{Ca}(\mathrm{OH})_{2}$ were not detected in Figure 7 , therefore, $\mathrm{CaSO}_{4}$ in the paste was completely consumed due to Equations 2-4, 7-10. 


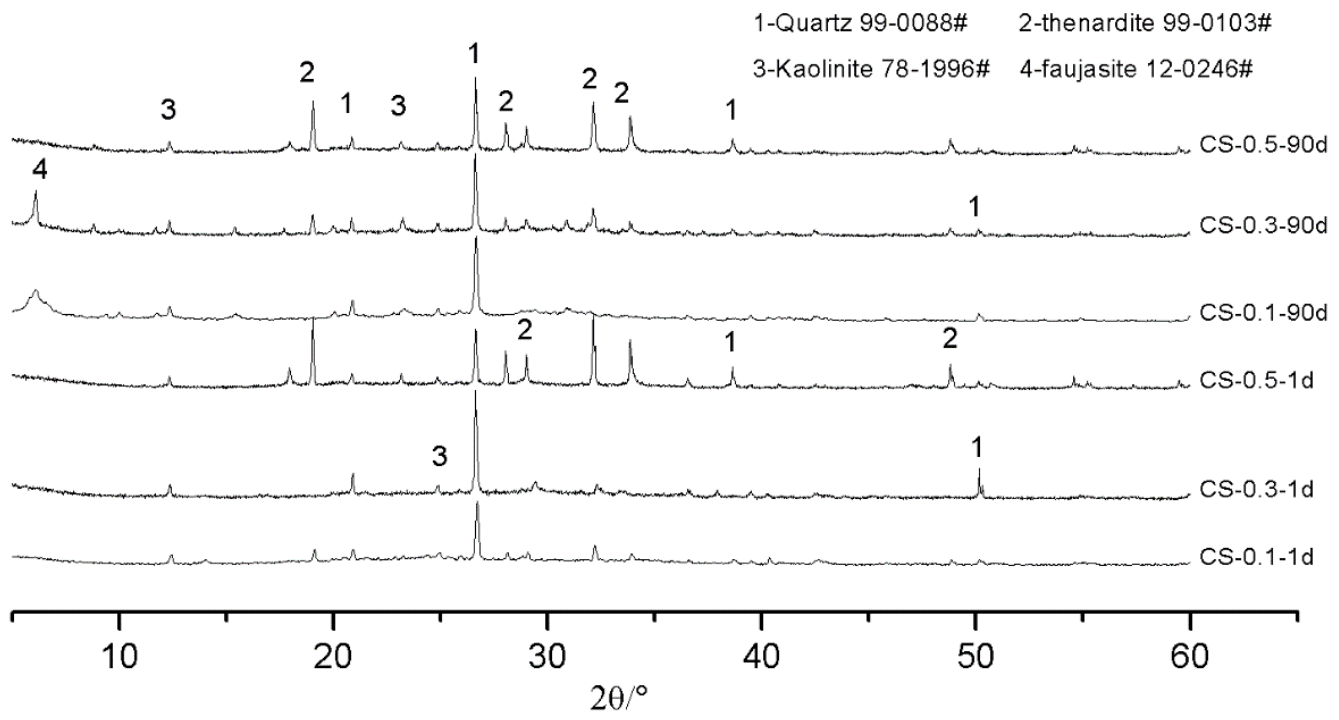

Figure 7. $\mathrm{X}$-ray diffraction of $\mathrm{CaCO}_{3}$-bearing samples (normalized to the $100 \%$ intensity peak of quartz of sample CC-0.1-1d )

\section{Influence of $\mathrm{Ca}(\mathrm{OH})_{2}$ on the Geopolymerization}

Boonjaeng S. et al. reported that pozzolanic reactions and geopolymerization occurred simultaneously in $\mathrm{SiO}_{2}-\mathrm{Al}_{2} \mathrm{O}_{3}-\mathrm{CaO}-\mathrm{Na}_{2} \mathrm{O}-\mathrm{H}_{2} \mathrm{O}$ system when $\mathrm{Ca}(\mathrm{OH})_{2}$ was the $\mathrm{Ca}$ source (Boonjaeng S. et al., 2014). The reactions were dependent on the concentration of $\mathrm{NaOH}$. When the concentration of $\mathrm{NaOH}$ was lower than $1 \mathrm{M}$ pozzolanic reaction (Equation 11) was dominant (Alonso S. and Palomo A., 2001 and Cabrera J. and Rojas M. F., 2001). When the concentration of $\mathrm{NaOH}$ was higher than $5 \mathrm{M}$ geopolymerization (Equations 1-8) was dominant. The concentration of $\mathrm{NaOH}$ in this research was lower but close to $5 \mathrm{M}$. In this research $\mathrm{Ca}(\mathrm{OH})_{2}$ also reacted with sodium silicate (Equation 12). When the $\mathrm{CaO} / \mathrm{Al}_{2} \mathrm{O}_{3}$ increased from 0.1 to 0.2 the initial and finial setting times of samples contained $\mathrm{Ca}) \mathrm{OH})_{2}$ accelerated from $330 \mathrm{~min}$ to $43 \mathrm{~min}, 520 \mathrm{mim}$ to $90 \mathrm{~min}$, respectively (Figure 8). However, the setting time varied little after further increase of $\mathrm{CaO} / \mathrm{Al}_{2} \mathrm{O}_{3}$. Therefore, when the $\mathrm{Ca}(\mathrm{OH})_{2}$ in solid was higher than $5.2 \%$ its effect on setting time can be neglected. However, the more $\mathrm{Ca}(\mathrm{OH})_{2}$ the higher strength of sample (Figure 8). The results of XRD (not shown in this research) $\mathrm{Ca}(\mathrm{OH})_{2}$ was not detected in all samples except sample $\mathrm{CH}-0.5$, which suggested that the optimum of $\mathrm{CA}(\mathrm{OH})_{2}$ per unit weight of metakaolin was between $9.6 \%$ and $15.9 \%$ in this research.

$$
\begin{aligned}
\mathrm{Si}_{2} \mathrm{O}_{5} \cdot \mathrm{Al}_{2} \mathrm{O}_{2} & +3 \mathrm{Ca}(\mathrm{OH})_{2}+6 \mathrm{H}_{2} \mathrm{O} \\
& \rightarrow 2 \mathrm{CaO} \cdot \mathrm{Al}_{2} \mathrm{O}_{3} \cdot \mathrm{SiO}_{4} \cdot 8 \mathrm{H}_{2} \mathrm{O}+\mathrm{CSH} \\
\mathrm{Na}_{2} \mathrm{SiO}_{3} & +\mathrm{Ca}(\mathrm{OH})_{2} \rightarrow \mathrm{CaSiO}_{3}+\mathrm{NaOH}
\end{aligned}
$$




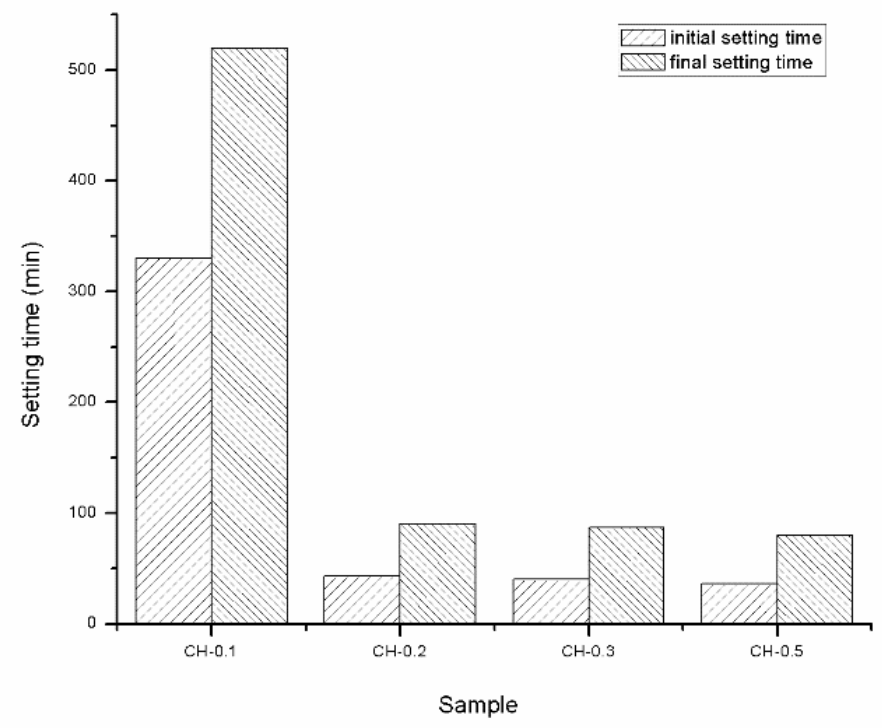

Figure 8. Setting time of each $\mathrm{Ca}(\mathrm{OH})_{2}$-bearing sample.

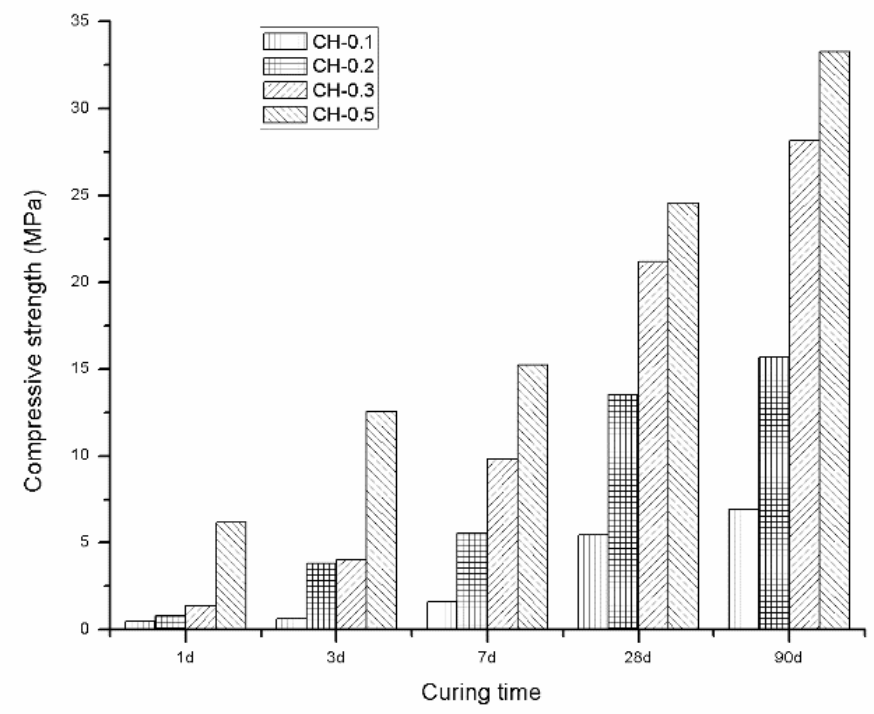

Figure 9. Compressive strengths of $\mathrm{Ca}(\mathrm{OH})_{2}$-bearing samples. 


\section{CONCLUSION}

The influence of $\mathrm{CaCO}_{3}$ on the geopolymerization varied with $\mathrm{CaO} / \mathrm{Al}_{2} \mathrm{O}_{3}$ and curing ages. $\mathrm{CaCO}_{3}$ did not show negative effect, however, acted as the soluble calcium source and aggregates in the preparation of geopolymer. In contrast to zeolite the formation of faujasite in 90-day cured sample decreased with the addition of $\mathrm{CaCO}_{3}$. Continuous formation of AFt in CaSO4-bearing sample resulted in strength reduction at long-term curing ages. The threshold of $\mathrm{SO}_{3}$ for preparation of geopolymer using CFB fly ash was between 9.8 and 16.1 per unit weight of metakaolin in this research. $\mathrm{Ca}(\mathrm{OH})_{2}$ reacted with sodium silicated to form calcium silicate and sodium hydroxide, which was helpful to the strength development. The optimum of $\mathrm{CA}(\mathrm{OH})_{2}$ per unit weight of metakaolin was between $9.6 \%$ and $15.9 \%$ in this research.

\section{REFERENCES}

1. Huang, Y. and Han, M. (2011) "The influence of $\alpha-\mathrm{Al}_{2} \mathrm{O}_{3}$ addition on microstructure, mechanical and formaldehyde adsorption properties of fly ash-based geopolymer products", Journal of Hazardous Materials, 193, 90-94.

2. Feng, D., Provis, J. L. and van Deventer, J. S. J. (2012) "Thermal Activation of Albite for the Synthesis of One-Part Mix Geopolymers", J. Am. Ceram. Soc., 95(2), 565-572.

3. Pimraksaa, K., Chindaprasirt, P., Rungchet, A. et al. (2011) "Lightweight geopolymer made of highly porous siliceous materials with various $\mathrm{Na}_{2} \mathrm{O} / \mathrm{Al}_{2} \mathrm{O}_{3}$ and $\mathrm{SiO}_{2} / \mathrm{Al}_{2} \mathrm{O}_{3}$ ratios", Materials Science and Engineering A, 528, 6616-6623.

4. Part W. K., Mahyuddin R., Cheah C. B. (2015) "An overview on the influence of various factors on the properties of geopolymer concrete derived from industrial byproducts", Construction and Building Materials, 77 , 370-395.

5. Fernández-Jiménez A., Palomo A., Sobrados I., et al. (2006) "The role played by the reactive alumina content in the alkaline activation of fly ashes", Microporous \& Mesoporous Materials, 91(1), 111-119.

6. Criado M., Torre A. G. D. L., Aranda M. G., et al. (2007) "An XRD study of the effect of the $\mathrm{SiO} / \mathrm{NaO}$ ratio on the alkali activation of fly ash". Cement \& Concrete Research,37(5), 671-679.

7. Zhang Z., Wang H., Provis J. L., et al. (2012) "Quantitative kinetic and structural analysis of geopolymers. Part 1 . The activation of metakaolin with sodium hydroxide". Thermochimica acta, 539, 23-33.

8. Alonso S., Palomo A. (2001) "Alkaline activation of metakaolin and calcium hydroxide mixtures: influence of temperature, activator concentration and solids ratio". Materials Letters, 2001, 47(1-2), 55-62

9. Silva P. D., Hanjitsuwan S., Chindaprasirt P. (2014) "The role of $\mathrm{SiO}_{2} \& \mathrm{Al}_{2} \mathrm{O}_{3}$ on the properties of geopolymers with and without calcium". Ceramic Engineering \& Science Proceedings, 34(10), 25-35. 
10. Suryavanshi A. K., Scantlebury J. D., Lyon S. B. (1996) "Mechanism of Friedel's salt formation in cements rich in tri-calcium aluminate". Cement \& Concrete Research, 26(5), 717-727.

11. Alonso S., Palomo A. (2001) "Alkaline activation of metakaolin and calcium hydroxide mixtures: influence of temperature, activator concentration and solids ratio". Materials Letters, 47(1-2), 55-62.

12. Rakhimova N. R., Rakhimov R. Z., Naumkina N. I., et al. (2016) "Influence of limestone content, fineness, and composition on the properties and microstructure of alkali-activated slag cement”. Cement \& Concrete Composites, 72, 268-274.

13. Gao X., Yu Q. L., Brouwers H. J. H. (2015) "Properties of alkali activated slag-fly ash blends with limestone addition". Cement \& Concrete Composites, 59, 119-128.

14. Qiao X.C., Cheeseman C.R. and Poon, C.S. (2009) "Influences of chemical activators on incinerator bottom ash", waste management, 29,544-549

15. Boonjaeng S., Chindaprasirt P., Pimraksa K. (2014) "Lime-calcined clay materials with alkaline activation: Phase development and reaction transition zone". Applied Clay Science, 95(6), 357-364.

16. Alonso S. and Palomo A. (2001) "Calorimetric study of alkaline activation of calcium hydroxide\&ndash;metakaolin solid mixtures". Cement \& Concrete Research, 31(1), 25-30.

17. Cabrera J., Rojas M. F. (2001) "Mechanism of hydration of the metakaolin-limewater system". Cement \& Concrete Research, 31(2), 177-182. 